This is a so-called personal version (author's manuscript as accepted for publishing after the review process but prior to final layout and copyediting) of the article.

Riad, S., Vaara, E. and Zhang, N. The intertextual production of international relations in mergers and acquisitions. Organization Studies, 2012, 33(1): 121-148.

Researchers are kindly asked to use the official publication in references.

\title{
The Intertextual Production of
}

\section{International Relations in Mergers and Acquisitions}

\author{
Sally Riad \\ Victoria University of Wellington \\ P O Box 600, Wellington, New Zealand \\ Tel. +64 44635079 \\ Fax. +64 44635253 \\ Email sally.riad@vuw.ac.nz \\ Eero Vaara \\ Hanken School of Economics \\ E M Lyon \\ Tel. +358 503059359 \\ Email eero.vaara@hanken.fi \\ Nathan Zhang \\ Tel. +64 274532283 \\ Email nathanzhang1978@yahoo.com
}




\title{
The Intertextual Production of
}

\section{International Relations in Mergers and Acquisitions}

\begin{abstract}
While studies on international management have focused on cultural differences and examined institutional specificities in various national business systems, conceptions of international relations have been left relatively underexplored. We argue that representations of international relations are relevant to international M\&As and contend that intertextuality offers a novel approach to examine these relational features of international management. Our analysis focuses on Sino-US relations in the context of the acquisition of American IBM’s Personal Computer Division (PCD) by the Chinese company, Lenovo. We demonstrate the ways in which facets of international relations are produced in media accounts of this acquisition, and analyze the intertextual dynamics entwined with their production. The analysis consists of three sections: constitutive intertextuality, manifest intertextuality and intertextual ideological undercurrents. These illustrate the variation in producing international relations through discursive themes (threat to security/peaceful rise), emotion rhetoric (fear/cheer) and ideology (cold war/globalism). Altogether, the paper elucidates the ways in which international M\&As are immersed in a seascape of intertextual international relations.
\end{abstract}

\section{Key words:}

Mergers and acquisitions, international relations, globalisation, intertextuality, ideology 
Once little known outside China, Lenovo catapulted to No. 3 in the world PC market (...) with its $\$ 1.75$ billion IBM purchase. The acquisition, the most high profile overseas grab by a Chinese firm, horrified many Americans, who saw a rising China set to gobble up flagship industries in the U.S. After all, IBM virtually invented the PC 25 years ago (Schuman, 2006).

The purchase [of IBM PCD], unique in Chinese commercial history, was more significant than the dollar value being discussed. The 'plot by global western enterprises to gulp up a large share of the Chinese market' was, in the eyes of some people, being dealt a powerful blow. This broadly perceived 'plot,' whether true or a fabrication, had in the past twenty years become the foundation of nationalist sentiment in China. An underlying anxiety had increased the West's distrust of China which in turn fed Chinese antagonism towards foreign politicians (Zhijun, 2006, p. 1).

Mergers and acquisitions (M\&A) are of increasing relevance to international management.

Such events often hold implications not only for organizations, but at times also for their respective nation states to the extent that international M\&As become entwined with international economic and political relations. Studies on international management have usually focused on cultural differences (e.g. Hofstede, 1980; Søderberg \& Holden, 2002) as well as examined institutional specificities in various national business systems (Quack, Morgan \& Whitley, 2000; Morgan, Kristensen and Whitley, 2001). Yet, conceptions of international relations in international management have been left relatively unexplored. This oversight has constrained the appreciation of the political and ideological dynamics that confront international organizations. M\&As, in particular, challenge organizations’ national affiliation and respective sense of ownership and territoriality. This takes place within a relational milieu in which a variety of texts - such as those produced by news media - continuously invite members of a given society to reflect on their national events in relation to a world made of nations (Andersen, 1983; Billig, 1995).

In this paper we argue for the relevance of understanding the intertextual production of international relations in M\&As. The premise of the argument is twofold. First, we maintain that conceptions of international relations are relevant to international M\&As. The field of international relations is largely concerned with relationships between nations (including foreign affairs and trade). Such relations set the scene for how an acquisition is presented and interpreted in the organizations' respective nations as well as potentially shape the political and 
economic context of the event. Second, we contend that intertextuality offers a novel approach to examine these relational features of international management. Intertextuality - the notion that a text is relationally bound to other texts - focuses on a lattice embedded in, and embedding, social and historical relations across texts (Bakhtin, 1986; Fairclough, 1992, Kristeva, 1980). Intertextual analysis, therefore, identifies the 'bigger picture' in a text: it brings into sharp relief how concepts harboured by a given society are engrained into the textual production of everyday life (Shapiro, 1989).

By focusing on the intertextual production of international relations in international M\&As, we introduce a new relational perspective on these events. We draw on literature that examines the nexus of organizational and national identity in M\&As (Ailon \& Kunda, 2009; Ailon-Souday \& Kunda, 2003; Vaara, Tienari \& Säntti, 2003; Vaara \& Tienari, 2011) and address its limitation by analyzing the ways in which texts are formed by, and give form to, international relations in a given merger or acquisition. Our analysis focuses on the US-Chinese relationship, arguably an important setting due to the expansion of the Chinese economy and its varied implications for Western economies (e.g. Kang, 2004; McDougall, 2006). The case in point is the acquisition of IBM's Personal Computer Division (PCD) by the Chinese company, Lenovo. We examine media texts due to their salience both to intertextual analysis (Fairclough, 1992, 1995; Meinhoff \& Smith, 2000) and to national identification (Andersen, 1991; Billig, 1995).

On December 7th, 2004, Lenovo, the largest PC firm in China, and IBM announced an agreement according to which the former would acquire IBM’s Personal Computing Division (PCD). This was the largest foreign acquisition by a Chinese company at the time. While there had already been extensive international acquisitions of Chinese firms, this landmark deal led attempts by Chinese firms to undertake cross-border acquisitions and was high in profile; it created the world's third largest PC business and drew both western and Asian media attention 
to Chinese acquisition activity. A Singapore-based commentator noted: 'They sounded the first canon. The Lenovo brand, which I had never heard of, became an international event' (Guan, 2004). This 'event' was not significant simply because it was a major international acquisition; rather, as our top quotes illustrate, it was the respective national affiliations of the organizations - and the event's international positioning - that defined its salience.

The top quotes appeared in two different sources (a magazine and a book), originally published in two different languages (English and Chinese). However, they both resonate with similar features: they establish the international relational significance of the event, they deploy predatorial language ('gobble up,' 'gulp up') and they articulate specific emotions ('horrified,' 'anxiety'). Yet, they are not identical; rather they offer different points of view: the first provides the reader with what many Americans 'saw', and the second addresses perceptions in the 'eyes' of some Chinese people. Such iteration and difference is at the heart of intertextual relations, the analytical focus of this paper. Inquiry into intertextual production is directed at both resonance and response (or reproduction and change). Accordingly, our analysis addresses the following research questions: What are the facets of international relations that surface in the media accounts of this international acquisition? What are the intertextual dynamics entwined with the production of these international relations in this acquisition?

The paper is organized as follows. First, we canvass the literature on international M\&As and address a gap within it through an introduction to international relations. Next, we introduce the intertextual approach to international relations in M\&A media texts, and outline the methodology for examining the Lenovo - IBM PCD case in English- and Chinese-language texts. This is followed by an overview of Sino-US relations and their practical implications for this acquisition. Subsequently, the analysis consists of three sections: constitutive intertextuality through discursive themes, manifest intertextuality through contrastive emotion rhetoric and intertextual ideological undercurrents. In closing, the conclusion elaborates on the contributions 
to international management in general, and M\&As in particular.

\section{International Relations and Intertextual Production in M\&As}

International M\&As have been studied from strategic (Calori, Lubatkin, \& Very, 1994; Puranam, Singh \& Zollo, 2006), human resource (Aguilera \& Dencker, 2004; Goulet and Schweiger, 2006) and cultural perspectives (Lubatkin, Calori, Very \& Veiga 1998; Morosini, Shane, \& Singh, 1998; Olie, 1994). Recently, culturally oriented scholars have focused on the role of discourse, language and text in shaping M\&A dynamics. For example, Vaara (2002) showed how narratives of post-merger integration draw on cultural discourse and Riad (2005) demonstrated the ways in which 'culture' is mobilized to different ends in integration processes. Studies have also addressed the dynamics of national identity and identification. The latter focuses on the processes by which people come to associate with a group (in terms of characteristics, interests, actions) and which determine and shape identity. For example, AilonSouday and Kunda (2003) elucidated the role of stereotyping in M\&As and Vaara et al. (2003) illustrated the role of metaphors in identity-building.

Meanwhile, studies of M\&As based on media analysis have examined the ways in which images of M\&As are constructed (Demers, Giroux \& Chreim, 2003; Hirsch, 1986; Schneider \& Dunbar, 1992) and the discursive processes underlying such constructions (Cummings \& Riad, 2007; Fitzgibbon \& Seeger, 2002, Koller, 2005). Other studies have focused on the ways in which certain ideas and practices - and not others - are legitimized in specific M\&As (Comtois, Denis \& Langley, 2004; Vaara, Tienari \& Laurila, 2006), including the dynamics of national and global discourses (Fursich, 2002; Riad \& Vaara, 2011; Tienari, Vaara \& Björkman, 2003). Although these studies have enriched the understanding of the role of national identification in forming and constructing identity, we still lack in-depth examination of the ways in which representations of international M\&As are politically and ideologically embedded in international relations. In what follows, we turn to this gap in the literature. 
Texts on international M\&As commonly attribute interactional dynamics to 'crossborder' or 'cross-cultural', the two often combined and facilitated by the construct 'national culture’ which is a key theme for research in international M\&As (e.g. Aguilera \& Dencker, 2004; Calori et al., 1994; Morosini et al., 1998; Olie, 1994). In his analysis of the increasing salience of borders, Hannerz (1997) discusses the tendency to assume that culture/culture and state/state borders coincide. The term 'cross-border' signifies territorial demarcation, implying conceptions of geo-political borders and their respective geo-economic interests. Indeed, there has been long-standing recognition in international relations that geo-political and geo-economic interests are entwined - at times in contradictory ways. However, such knowledge has yet to be explicated in the international management literature, specifically that on M\&As. In this paper, we maintain that international business and management are neither neutral nor discrete activities, nor are they mainly about overcoming cross-cultural challenges, but also cross-border dynamics - specifically those entwined with conceptions of the nation state and its relations with others. More specifically, we adopt an intertextual approach to examining the ways in which international relations are produced in media texts.

\section{International relations and national identification}

The term 'international relations’ signifies both a specific interest in relationships between nations as well as an area of study (Merriam-Webster 2011). Whereas the interest initially focused on foreign affairs and policy, it expanded to include international phenomena (e.g. globalization, ecological sustainability), international bodies (e.g. UN, EU) and subnational entities (e.g. political parties, expert networks) (Rochester, 2010). As a field of study, it developed early in the $20^{\text {th }}$ Century in the West and by 1920 it had appeared as a term in seminal texts (Der Derian, 1989). Its increasing relevance for study beyond its initial disciplinary home within political science has led to its extension across academic disciplines such as geography, history, economics, sociology and philosophy (Encyclopaedia Britannica 2011); however, its 
relevance has yet to be explicitly addressed in international management.

In recent years, concepts premised on the 'national' have been overshadowed by the interest in globalization. In the organizational literature, for example, Ailon and Kunda (2009) critique the tendency of globalization theorists to emphasize transnationalism at the expense of the national boundaries that are expressed within multinational organizations. Based on ethnographic research, they illustrate how transnational communities become another arena for displaying the strength and persistence of national identities, arguing that 'globalization's cultural forms are not 'beyond' or 'above’ the nation' (p. 709). This resonates with Holden’s (2006, p. 63) argument for 'putting the nation back into the transnational'. He poses the paradox that the transnational is often only comprehensible in relation to the nation. In a similar vein, we problematize the tendency in international management to approach M\&As as if they were 'above' or 'beyond' international relations, arguing that the latter is paramount to understanding the ways in international M\&As are defined. Yet in the first instance, understanding the 'international' is premised on understanding the 'national', the term that inhabits it. The reverse is also relevant: to conceive the 'national', one implicitly considers what lies beyond its limits, the 'international'. This mutual definition of opposites is both textually and socially constituted.

The 'nation' been studied extensively in political science, sociology and social psychology. Consequently, 'nationalism' has been conceptualized in various ways: as institution, social movement, ideology, or discourse (Gellner, 1983, Freeden, 1998, Özkirimli, 2000; Smith, 2001; Sutherland, 2005). Drawing on Anderson's (1983) concept of nations as 'imagined communities,' our starting point is to approach the 'nation' as a construct founded on the basis of shared understanding of history and continuity. We use the term 'national identity' to refer to the characteristics deployed to distinguish a 'nation' and individuals' sense of belonging to it; and we use 'nationalism' to refer to the collectivism that mobilizes people as a 'nation', including attitudes to national identity and actions to sustain it. Rather than approach 
the 'nation' as a reified category with fixed meanings, we emphasise the narration of nation (Bhabha, 1999). This allows us to shift the focus from the objectified entity to the statements that produce it, a notion to which we now turn.

\section{International relations, intertextuality and the media}

The relevance of textuality was explicitly argued in International/Intertextual Relations, an anthology that focused on the 'space between,' the intertexts constructed in international relations 'between the margins and the body of international theory, between textual politics and world politics’ (Der Derian, 1989, p. 4). This central tenet is increasingly salient to the current world climate. Its basis is that our understanding of international relations is mediated by texts as modes of representation, and thus by the mechanisms that constitute them such as discourse and rhetoric (Shapiro, 1989). Against this background, research in international relations has turned to discourse and intertextuality for both analysis and theorization (Chilton, 1996; George, 1994; Lapid, 1996; Milliken, 1999; Schlosser, 2007). We draw on this body of work to underline the intertextual production of international relations in international M\&As.

The premise is that the production of national identity relies on historic territory as well as common myths, memories, economy and legal rights and duties (Smith, 2001). These facets are linked to each other and to people through a web of texts and intertextual relationships. Kelly-Holmes (2000) argues that the act of sharing texts (both official and unofficial) that circulate in a given society contributes to its common identity. From this perspective, identity depends on texts for its production, and intertextual relations form a basis for national identification. In discussing national identification as a performative discourse in international relations, Lapid (1996) situates language and rhetoric as its productive resources. Members of international organizations, as with wider societies, are continuously and subtly reminded of their 'national place in a world of nations' (Billig, 1995, p. 9). Hence, forms of international relations should be understood as specific articulations founded on particular histories of, and 
between, nations. Such collective understanding of 'other' nations is shaped by 'institutionalized interests with respect to how we process information about remote experiences' - with the media playing a key role (Shapiro, 1989). This underscores the relevance of analysing the ways in which various media construct and represent international relations.

In particular, by involving individuals in sharing a set of common texts, news media act like a nationalist novel, engaging people in national discourse as a national community (Andersen, 1991). Since certain habits of thought need to be reproduced daily, news media play an important role in producing a nation and its relational orientation to other nations (Chang et al., 2006). Newspapers 'flag' national frames of reference through their text and so participate in 'banal nationalism' (Billig, 1995). They position their readership in national terms and invite them to reflect on their nation in relation to others - for example, discussing nationalism in other countries as 'irrational' and their own as 'patriotic'. In a similar vein, we focus on media production of international relations; we turn to elaborate on the approach adopted.

\section{An Intertextual Approach to International Relations in M\&A Media Texts}

The analytical approach to this paper rests on a theory of texts as dialogues, or intertexts. Every text is dialogical, gaining its meaning in relation to other texts (Bakhtin, 1986). Thus, intertextuality denotes the ways in which works of literature are produced both through resonance with, and in response to, previous works of literature (Shapiro, 1989). The process of academic publishing is a prime example of intertextuality whereby texts are cited and re-cited in agreement and difference. Ideas core to intertextuality were first expressed in the works of Bakhtin (Bakhtin 1981, 1986), who placed relationality at the heart of meaning. It acquired prominence, however, through Kristeva (1980), who is credited with coining the term through her notion that a text is 'a permutation of texts, an intertextuality.' Whereas the superficial observation on intertextuality is that all texts contain traces of other texts, its analytical potential lies in the recognition of textuality as an ongoing process, wherein production also involves 
interaction between texts as well as the anticipation of reading and reader life experience (Boje, 2001; Bojet et al., 2004; Meinhoff \& Smith, 2000).

Drawing on the works of Bakhtin and Saussure, Kristeva's notion of intertextuality renders each text a 'mosaic' $(1980$, p. 66, 69) that is part of a larger mosaic of texts. The intertextual mosaic is mapped along two axes: a vertical axis connecting the author to the reader of the text, and a horizontal axis that connects the text to other texts. Textual production is redistributive, its knowledge cross-referenced by different producers (Boje, 2001; Meinhoff \& Smith, 2000). In posing the question, ‘Only connect?’ Keenoy and Oswick (2003, p. 136, 138) proceed to argue that intertextuality both foregrounds notions of relationality and 'represents a co-constructed (re)blending which is continuously being reconstituted.' The intertextual trajectory to each text holds both historical and social coordinates (Kristeva, 1980, p. 36). Hence, intertextuality is not only about how texts are interrelated, but also about their inherent historicity and the ways in which they are entwined with social practices (Boje, 2001; Keenoy \& Oswick, 2003). In other words, a text is a form in which various social relations - such as international relations - are embedded (Fairclough, 1992).

Since dominant textual practices 'give rise to the systems of meaning and value from which actions and politics are directed and legitimated,' intertextual inquiry is relevant for studying privileged forms of representation, such as media texts whose dominance shapes the way the world is constructed (Shapiro, 1989, p.13). Intertextuality is enmeshed with a struggle in the production and distribution of mass consumption wherein the media play a crucial role. Fairclough (1995) discusses ‘discourse representation’ as a form of intertextuality in which parts of texts become incorporated in other texts. Since media texts are qualitatively continuous with experiences of everyday life, they have served both to generate theories of intertextuality and to illustrate it particularly well (Meinhoff \& Smith, 2000). More specifically, they include and edit quotes to represent people’s voices. This process involves contextualization: quotations are not 
simply citations but serve a purpose. Through selection and change, they both reproduce and reinterpret events across participants in ways that redefine meanings about the world which the various cited actors inhabit. For example, they can justify and empower what one side does or says and ignore or deride the other.

To Fairclough $(1992,1995)$, focus on intertextuality demonstrates how texts can both interact with and transform prior texts, and reorganize existing conventions to generate new ones. Since intertextuality offers the interface between context and text, attention is directed to discourses that shape the production of a text. Fairclough (1992, p. 117) discusses 'constitutive intertextuality' and 'manifest intertextuality,' the former focusing on the interrelationship between the discursive features in a text, and the latter on intertextual elements such as rhetoric. Specifically, emotion rhetoric plays a relevant part in shaping a news text's (implicit or explicit) argument. The textual depiction of rich contrasts and alternatives of emotion is used in developing and representing activities and relations (Edwards, 1999). Through emotion rhetoric, media texts generate 'a feeling of participation in... the world outside, being recreated inside the articles’ (Niemeyer et al., 2007, p. 211).

We examine both constitutive and manifest intertextuality in this paper. To these two, we add a third facet of intertextual analysis: ideology (Fairclough 1989, van Dijk 1998). Texts 'are the embodiment of an existing socio-ideological dialogue' between different groups in society (Vargova, 2007, p. 423). Accordingly, ideological premises to international relations are reproduced in and through texts including those that cover the news (Akhan-Majid \& Ramaprasad 1998). Our approach to ideology is as 'an adaptable but internally coherent belief system' that social actors use to interpret or explain society, with the practical function of 'maintaining or changing the political status quo' (Sutherland 2005, p. 188). To Fairclough (2003, p. 9), ideologies are intimately linked to discourse, and contribute to establishing, maintaining and changing social relations. Hence, they underlie constitutive and manifest 
intertextuality. Figure 1 represents our theoretical approach.

\section{Insert Figure 1 about here}

\section{Methodology}

The study is based on an analysis of the Chinese Lenovo’s acquisition of American IBM PCD. Our corpus consists of media accounts of the acquisition in the English language, and media accounts in Chinese. The time-line for the material included is from early December 2004, when the acquisition announcement first circulated in the public sphere, to the end of August 2005, when IBM PCD was officially 'transferred' to Lenovo. The research made use of 590 articles in both English and Chinese languages. The selection of the news media spanned sources with prominent national and regional presence, business interest as well as industry focus. The English corpus consisted of 240 articles across BusinessWeek (8), CNET News (36), Computerworld (20), Financial Times (31), Fortune (2), Newsweek (4), Sinocast (79), The Economist (5), The New York Times (17) and The Wall Street Journal (38). The Chinese corpus consisted of 335 articles across 21 Century Economy Report (49), China Business (53), China Business Post (31), China Computer World (33), Hong Kong Economic Times (95), Lian He Zao Bao (29), Liberation Daily (15), People’s Daily (20) and Southern Weekend (10).

The vertical textual axis for a text considers its distribution, circulation and audiences. In analyzing the corpus, we maintained two distinct vertical axes for the texts; these separated the English- and Chinese-language media accounts in relation to the context of the readership and publication. This was relevant to understanding the intertextual relationship - whether of repetition or response, agreement or difference - across the media coverage. In analysing the horizontal intertextual axis, we focused on identifying traces of other texts by examining explicit references to other media sources and speakers or parts of texts incorporated into the text (quoted or interpreted). In categorizing the material, we concentrated on constitutive intertextuality, manifest intertextuality and ideology. 
First, we focused on constitutive intertextuality by examining international relational discursive themes in media accounts of the acquisition. We approached the texts initially by means of open coding (Titcher, Meyer, Wodak \& Vetter, 2000), identifying recurring themes related to international relations including common terms as well as patterns of repetition or response. This led to an identification of the main discursive themes: 'threat' to US national security and economy in English, and China’s 'peaceful rising' in Chinese.

Next, we examined manifest intertextuality through micro-elements central to the international discourses by focusing on emotion rhetoric. Though we could identify other interesting linguistic features, we focused on emotion rhetoric because such rhetoric serves to 'to open and close' readers' 'mental frontiers'. In analysing media representations of relations across European countries, Niemeyer et al. (2007, p. 193) identified that emotion rhetoric features cultural stereotypes of both fear and enjoyment. These played a central role in both sets of texts analysed here. English-language texts included words that signified negative emotions such as ‘fear' and 'concern', while Chinese texts included words of elation such as 'cheer', 'courage,' and 'pride.' We are not suggesting absolute agreement in discursive themes or linguistic elements, but point out that both constitutive and manifest intertextuality resonated with similar, consistent themes within each horizontal axis. However, when the two axes (English and Chinese) were compared, one could identify difference and change: the reorganization and transformation of meaning through both resonance and response.

Finally, we focused on identifying ideological premises of international relations produced in accounts of the acquisition. 'Cold War' and 'globalism' were two key ideologies in the media texts. These ideologies compete both within and across the vertical axes, and are at odds with each other with regards to the acquisition.

Two limitations are posed. First, such analysis is challenging since it requires one to place specific texts in their social and intertextual contexts. However, the fact that, as authors, we are 
English and Chinese speakers provided us with the opportunity to go beyond individual texts to identify subtle social and linguistic aspects that could pass unnoticed. Second, the analysis is not exhaustive of all themes that could be gleaned from media sources on this case; as Keenoy and Oswick (2003, p. 140) note, 'it is impossible to attend to all the potential intertexts of any particular discursive event.' Our focus was on themes that contribute to the production of international relations in texts on organizational events. This case is intended to offer analytical generalization on intertextual processes which, upon due reflection, can be extended towards inquiry into other cases (Tsoukas, 1989). In what follows, we sketch out the relational grounds within which the seeds of the acquisition were sown, and then present practical implications of the international relations inherent to the acquisition process.

\section{A snapshot of Sino-US relations at the time of Lenovo's Acquisition of IBM PCD}

The year this acquisition was announced, 2004, marked 25 years since the return of Sino-US relations in 1979. The US had not recognized the People's Republic of China for 30 years after its inception, and had withdrawn its personnel from mainland China in early 1950. Subsequently, the two met on the battlefield during the Korean War. The 1970s, however, witnessed gradual emergence of relations formalized with the establishment of mutual embassies and bilateral trade agreements (McDougall, 2006; Song, 2006). This enabled increasing trade and cooperation between the two, though there had also been 'ups and downs' in the relationship (Doyle, 2007; FMPRC, 2011). By the time of the merger, for 10 years commerce had drawn America and China together. Commentators noted that during that period, the US had adopted a two-track policy that involved focus on both economic and geopolitical relations: both welcoming China's economic growth as well as ensuring readiness of its own forces to meet any overt challenges (Doyle, 2007; The Economist, 2010). The latter was driven by differences in geopolitics, notably with regards to relations with Taiwan and North Korea, which had led commentators to reflect on the developing ambivalence: the potential for a new 
cold war between the two but also the observation that in terms of geopolitical power neither had the inclination for an overt challenge (Yuan, 2002; The Economist, 2009).

Turing to economic and business relations, by the announcement of the acquisition China had been undergoing profound economic and social reform for more than 25 years. The reform, described by the catchphrase 'socialism with Chinese characteristics' underwent several stages from opening trade with the outside world to creating a market pricing system and banking system reform (Kang; 2004; Li, 2005; Tan \& Tan, 2003; Zhijun, 2006). China’s reform has been 'characterised as one without-a-theory' (in the sense of an articulated formal approach) but underpinned 'by a pragmatic mindscape' (Zu 2007, p. 1504, 15). Yet, while it had come to enjoy a certain acceptance, it was also approached with wariness since it blended in significant state influence over the economy, a position different from democratic capitalism (Li, 2005; Kang 2004). Concern rose within China over the country's portrayal by the American media and its 'demonization' in western representations and this was addressed through several high profile books as well as increasingly vigilant regional press (Kang, 2004; Zhang 1998; Zhijun, 2006). Writing in 1998 (p. 93-94), Chow had coined the term 'King Kong syndrome’ to refer to representations that depicted China as a spectacular monster. He noted that feelings of fear continued to characterize the media's portrayal of China at the time, which often involved a 'process of othering' that contrasted China to the US.

Since then, commentators have noted an ongoing dilemma. On the one hand, they described the US concern over China's growing bilateral trade surplus and its different view with regards to the floating of the Chinese Yuan. On the other hand, they recognized that China's leaders need to deliver ongoing and increasing economic wellbeing to their country. Yet whereas there has been ongoing 'uncertainty' on both sides as to where the relationship will lead through its 'mix of partnership and rivalry', politicians in both countries increasingly attempted to work on antidotes to apprehensions about the relations on both sides (The Economist, 2007, 
2009, 2010, p. 13). The central issue is that increasingly, China and the US are 'in the same bed' with 'interlocked’ economies (China as the world's largest creditor and the US its biggest debtor) (Song, 2006; The Economist, 2009, p. 15); and, with two of the world's largest populations and economies, their relationship matters to the rest of the world (Doyle, 2007).

\section{Implications of international relations for Lenovo's Acquisition of IBM PCD}

Lenovo’s acquisition included IBM’s ‘Think’ brand notebooks as well as PC-related R\&D centres, manufacturing plants, global marketing networks, and service centres. The announcement followed more than two years of mutually instigated discussion and reviews of the possibility of the acquisition. Like other M\&As, media coverage presented strategic rationales and potential complementarities; however, in this case, interest in the ChineseAmerican relationship also gained ground in both English- and Chinese-language media. Commentators explicitly indicated the attention accorded to the acquisition within the context of the countries’ international relations: ‘...Americans won’t take the new deal lightly... concerns have long hung over the US-Sino relations’ (Hitt, 2005). These relations shaped the acquisition process and various integration decisions (Table 1).

To start with, the special attention accorded this acquisition was exemplified through the involvement of the US Committee on Foreign Investment in the US (CFIUS). Whereas CFIUS reviews are carried out routinely for examining the impact of foreign buyers acquiring US assets on US national security, full reviews like the one undertaken for this acquisition are less than $1 \%$ of the total. The full CFIUS review, in turn, prolonged the acquisition process. Further, to allay apprehensions over a Chinese acquisition of a US firm, Lenovo announced several decisions including the following: a decision not to relocate certain groups of employees, a decision to locate the head-office in New York (though the acquirer was based in China), and a decision to separate American employees - especially researchers - from Chinese employees. Such decisions were to have practical ongoing consequences after the acquisition. Further, 
investors were sought for the new Lenovo in an attempt to detract from the stake held by the Chinese Academy of Sciences in the new organization. Another symbolic decision included making English the official language of the new Lenovo (a point to which we return). Postacquisition, Lenovo appointed an American as CEO rather than someone from China. Yet, in 2006, the US State Department, previously a large IBM PCD client, announced that 16,000 computers it had already bought would be used for prosaic matters and excluded from sensitive 'classified' work; this was couched within changes in its procurement processes due to the changing ownership (The Economist, 2006).

\section{Insert Table 1 about here}

\section{The Intertextuality of International Relations in Lenovo's Acquisition of IBM PCD}

We now focus on the intertextual dynamics of the international relations as they surfaced in English- and Chinese-language media texts covering this acquisition. These dynamics are presented through three facets of intertextual analysis: discursive themes (constitutive intertextuality), emotion rhetoric (manifest intertextuality), and ideology. Table 2 summarizes our main findings.

\section{Insert Table 2 around here}

\section{Constitutive intertextuality: International relational discursive themes}

The Lenovo/IBM PCD acquisition offered a textual site for the enactment of the broader relationship between the US and China. The themes presented here serve a twofold purpose: they illustrate intertextuality between English- and Chinese-language media texts and the ways in which the textual inclusion of international relations featured both resonance and response, iteration and change. English-language media texts included representations of the acquisition as a 'threat' to US national and economic security. On the other hand, while reporting on the 'threat' claims, the Chinese media texts both interact with, and transform that image into one of 
China’s 'peaceful rise' and its economic policy of 'going out.'

\section{A threat to US security and economy}

Media texts in English report on reactions to the acquisition as representative of China as a 'threat' to US national and economic security. The 'threat' theme included the general economic expansion of China and specific concerns around technology. The concerns were accentuated by IBM's role as an 'icon' in the development of modern information technology, and what the deal meant about China’s rapid technological advancement (Table 2). The following is typical cautionary example:

China is rapidly becoming a major force in developing new technology, posing a significant economic threat to the United States (Frauenheim, 2005).

This media text also quoted comments on the acquisition made by a former US official indicating that the threat is not simply economic, but security-related as well:

'In an effort to assure Western companies that power sources and road access to a given site will be plentiful and well-maintained, Chinese promoters sometimes let slip that infrastructure in the area will receive consistent support and priority because the government wants to attract certain technologies that can be used in the Chinese defense and military industries.'

Such 'experts' were often cited in the media coverage (Table 2). In this context, they seemed to be used as authorities legitimating the claims concerning national security threats:

'My concern here is that we're going to reach a point where economic security becomes an issue of national security’ (in Hitt, 2005).

The threat to US national security theme was entwined with the representation of Lenovo as a 'Chinese government business' because the state-owned Chinese Academy of Sciences (CAS) was a major shareholder in Lenovo. The acquisition was at times presented as a national government-initiated strategy in China as in the following statement in The Economist:

Lenovo's move is the latest example of big Chinese firms aggressively expanding abroad under orders from their government ...

Other significant themes in the threat discussion were notions of unfair market practice and the loss of US jobs to China. In terms of the former, politicians were quoted discussing the 
acquisition as an attempt instigated by the Chinese government to take over the international PC market and to conduct industrial espionage:

Some US officials also fear the deal would give China a toehold in the corporate world from which they could conduct industrial espionage. Lenovo was launched in the mid-1980s with an investment from the state-controlled Chinese Academy of Sciences, and the academy would retain a $30 \%$ stake in the newly organized company; IBM would have an $18.9 \%$ stake ... 'The Chinese government runs a non-market economy which does not play by the rules of fair trade... This sale could lead to the Chinese government unfairly taking over the global market for personal computers' (Hitt, 2005).

The latter theme on the acquisition as a threat to the economy included discussion of the uneasy national trend of the US losing jobs - or 'outsourcing' them - to China as stated in following text:

In the past few years, China has emerged as a major player in the computer industry... many US tech companies are establishing research centres in China. China's growing technology economy is part of a broader pattern of tech work being shipped abroad that worries some US labour advocates (Frauenheim, 2005).

We now turn to a discussion of the intertextual relationship between Chinese-language media texts and English-language media texts, illustrating how the former interacted with the latter and transformed them (Fairclough, 1992, 1995) in through both resonance and response.

Intertextuality on 'threat' and response through China's 'peaceful rise' when 'going out'

Media texts in Chinese featured several main strands that described and responded to the 'threat' notion circulated in English media texts; these exemplify Fairclough’s (1995) concept of intertextual struggle in the production of mass consumption. The textual response included two extensively iterated and significant catchphrases on China: its 'peaceful rise' and its active efforts at 'going out.' Both figures of speech are relational and international in their focus: 'China rising' is relational, gaining meaning only relative to other nations, and its organizations would be 'going out' into other nations in the world. In addressing the former, texts included a discussion of the political controversy as instigated by certain thought in the US to which the acquisition represented 'strategic competition between countries' (Wu, 2005), framing it within the Sino-US inter-national relationship and downplaying the 'threat'. For example: 
Lenovo had acquired IBM PCD ... America has had fears of the rising China for a long time. Right now, seeing Chinese companies cross borders to acquire famous American brands, it is naturally easy for them to have the illusion of China as an approaching wolf that is going to hunt them down. It is understandable. Hence, China should not be too worried about the America's 'China threat' discussion (Lianhe Zaobao).

Such texts presented a description of 'politicisation' of the acquisition in the West and its negative implications for Chinese firms as in this example from $21^{\text {st }}$ Century Business Report:

The US, the country with the most free foreign investment policy, holds the highest political risk among developed countries because of the clear tendency for politicisation ... The reasons used for foreign investment protection are normally 'national security' and 'culture and ethnic tradition'.

Chinese-language media texts out of Singapore also included both issues. As can be noted from the examples, the acquisition was presented in terms of China's firms 'going out,' the term used to describe internationalisation, which is not quite 'expansion'. In responding to the claims, the notion of 'threat' was re-organized into the textual conventions of China's 'peaceful rising,' which in turn was normalized as 'common' (Table 2). The following is a typical example:

Last year, Lenovo acquiring IBM PCD was almost blocked by CFIUS. China’s peaceful rising was seen as political threat, and the merger as an 'economic threat' ( $21^{\text {st }}$ Century Business Report).

More generally, the acquisition was presented as an opportunity and a herald of things to come, as ‘a good beginning' for the official policy of 'going out' (Table 2).

As we have illustrated in this section, intertextual-international relations across discursive themes both resonate and respond, including repetition and difference, iteration and change. A key example of this intertextual relationship was illustrated through the threat/peace binary. While contrasting notions, they also supplemented each other allowing change in representation, a notion that we further develop in the next section.

\section{Manifest intertextuality: International relational emotion rhetoric}

In illustrating manifest intertextuality, we focus on emotion rhetoric as a discursive resource deployed in producing international relations in the acquisition context. Newspaper texts invoke emotions on an everyday basis and a key feature in its deployment is rhetoric 
(Edwards, 1999). By portraying and eliciting emotion on a large scale, the mass media not only defines what we know about the world, but also how we feel about it (Doveling et al., 2011). This unfolds across a range from the local to the international. We draw on Coupland et al.'s (2008, p. 330, 332) notion of 'emotion language as a rhetorical performance' in which descriptions of emotion are conceived as a linguistic phenomenon, entwined with strategic evaluational claims. They discuss how, 'emotion words are used rhetorically to construct events in or out of the ordinary.' Emotion is deployed in a range of oppositional and contrasting texts through 'situated rhetoric of description and counter-description' (Edwards, 1999, p. 271). This includes not only specific terms (such as 'fear'), but also a range of vivid metaphors. Here, we illustrate the international intertextual relationship between 'concern' and 'fear' on the one hand, and 'cheer' or 'pride' on the other. The emotion rhetoric deployed in English- and Chineselanguage texts featured both intertextuality and contrasting pitch; each is discussed in turn. English-language texts presented two sets of actors, those with political security and economic security interests, and those with interests in IBM as an American icon. In terms of the former, the media commentators deployed emotion expressions in their texts such as 'fear' and 'concern' with regards to the influence of the acquisition on the US. It is relevant to note that fear is increasingly implicated, and shapes, the 'geopolitics of everyday life', in Pain and Smith's (2008) terms. The authors note that it is 'written on the world' in ways that include news media, which serve to connect geopolitical and everyday fear.

In earlier sections of this paper, we used several quotes that deploy such terminology, notably Hitt (2005) wherein 'Republicans worried' and 'US officials fear.' These are set in a context of ‘tension'; for example:

Political tensions between the US and China appear ready to rise as economic ties between the two nations deepen... for politicians like Mr. Manzullo, the transaction fuses the panoply of fears about China....

When attempting to represent restrained sentiments, the term 'concern' was used:

The IBM deal has rankled three Republican congressmen, who expressed concern that the Chinese 
government would control 'advanced US technology’ (Wall Street Journal).

Emotion rhetoric came through strongly when explicitly using the word 'fear.' The term also appeared in titles such as in The Economist, 'I Spy Spies; Fear of China,' and in the Financial Times, 'Lenovo chief dismisses US security fears of IBM acquisition.’

The other position from which emotion rhetoric is deployed represents the voices of IBM PC customers. Generally, negative emotions were articulated through terms such as 'disappointed,' 'dismayed’ or 'worried.' The IBM PC was represented as iconic to the US; hence, selling the business to a 'Chinese' company 'is hard to swallow' for IBM computer users as in this example from Computerworld:

Although many users said last week that they understand the motives behind IBM's decision to sell its PC business, some found it hard to accept the planned sale of the product line ... 'It really is an American icon, and to see that get sold off to a Chinese company is kind of disappointing,' said Steven Gedwillo, a resource manager at Omaha Woodmen Life Insurance Society in Nebraska ... Ike Hunley, a systems programmer at Blue Cross and Blue Shield of Florida Inc. in Jacksonville, said he was dismayed by IBM's move, which he called 'just more selling off of America... piece by piece'.

These texts focused on IBM's popular ThinkPad laptop computer, with its expensive hightech image and celebrity owners such as $\mathrm{Al}$ Gore and Walter Cronkite, and the potential that it would 'lose its edge’ when sold to a ‘cut-price’ Chinese manufacturer (Table 2).

Media accounts in the Chinese language, in turn, featured an intertextual relationship to the above accounts by describing and commenting on the emotion rhetoric in the US:

When Lenovo acquired IBM PCD, a few Americans found it hard to accept the merger emotionally (People's Daily).

Such accounts also addressed the notion of 'fear' in the US. The following is an example in Liberation Daily:

The US is afraid of big governments and big companies. When Lenovo acquired IBM PCD, an American senator claimed that Lenovo wanted to control the US PC market, and that it would threaten the US's national security ... .

Examples could also be found in Chinese-language accounts out of Hong Kong, where commentators reported how the 'acquisition has caused nervousness overseas' (Wu, 2005), and 
in Lianhe Zaobao out of Singapore, placing the 'shocked' reaction in the context of international relations:

In the long term, the growth of China's economy and army power will challenge the US's position in the Asia Pacific, even at the global scale. More and more Chinese companies are buying western counterparts; Lenovo acquiring IBM PCD, shocked the US’s upper society.

The 'concern' and 'fear' entwine with the use of the predatory eating trope, such 'gobble up’ or 'take a bite.' A symbol of China in English-language media texts was the dragon. This image facilitated the eating trope as in The Economist title, 'The Dragon tucks in'. On the other hand, Chinese media texts also deployed 'eating,' but through a very explicit and subversive expression, that of 'snake-eat-elephant' - a parody that is a traditional Chinese expression of a successful manoeuvre. The trope became a popular means of framing the relationship in Chinese-language texts (Zhijun, 2006). It was then included as a cautionary tale in Businessline under the title 'A snake-eat-elephant story.' Such representations position the organizational events within international relations. In Chinese-language texts, the parody featured in several titles as well as in the text; as in this example in $21^{\text {st }}$ Century Business Report:

Lenovo acquired IBM PCD ... Because of this 'snake-eats-elephant' international acquisition, this date will be written into the history of Chinese companies' internationalisation.

In contrast to English-language texts, the emotion rhetoric in Chinese-language texts was predominantly one of elation in which the acquisition inspired a sense of 'greatness.' For example, various articles in 21 Century Business Report suggested that the sense of greatness should come from the nation's 'world spirit' and the 'feeling of a mission'. The acquisition was described as having 'increased Chinese ambition' and as representing ‘courage'. Attempts were also made to link the Chinese media accounts to Chinese people's national sentiments through an explicit intertextual reference as in the following from Liberation Daily:

[Chinese] media's comment on Lenovo's acquisition articulates with people’s psychological expectation towards Chinese international mergers and acquisitions: that they are on the mission to revitalize the Chinese nation and make it proud. The company which participated in the merger and the audiences are all very excited. 
By examining manifest intertextuality, the analysis of emotion rhetoric illustrates that whereas one can identify intertextual iteration of certain discursive elements, these do not reproduce identical meaning, but are used to ground response in an effort to change predominant understanding. This is not to suggest that international relations simply rest on the construction of national-level us/them binaries; rather, there can be difference within each nation and unison across nations, as our next section on ideology illustrates.

\section{Ideological undercurrents in international intertextuality}

In this final section to the analysis, we focus on the intertextual production of international relations through ideology. Two main ideological premises were implicated in textual representations of the Lenovo-IBM case. In the first ideological undercurrent, the Cold War and its conceptual repository shaped the representation of the relationship. China and the US had traditionally been viewed as potential adversaries (Guthrie, 2003), fuelled by an underlining Cold War ideology. Such an ideology, in turn, can both construct and constrain actors’ approaches to foreign policy and relations (Carragee, 2003; Stuckey, 1995). The second ideological undercurrent flows in opposition to the former, and is premised in globalism. Here, the term 'globalism' is used to signify an ideology that advocates the process of globalisation premised in the primacy of economic growth and underpinned by the role of free trade and a free market in stimulating such growth (Fairclough \& Thomas, 2004; Steger, 2001). Whereas the Cold War ideology reifies state borders, globalism assumes their erosion. We discuss the intertextual dynamics instigated by these ideological undercurrents in turn.

\section{'Cold War'}

The intensifying fears have parallels with those a decade ago of a Japanese economic takeover but with an overlay of military and ideological tension. Japan was a free-market democracy staunchly allied with the US, while China's blend of communism and capitalism, and its own geopolitical ambitions and nuclear arsenal, make many Americans nervous (Hitt, 2005).

While 'war' is a common metaphor in merger and acquisition discourse (Cummings \& 
Riad 2007; Koller, 2005), this quote illustrates the specific 'ideological tension’ in another form of encounter: the Cold War. Broadly speaking, the Cold War can be defined as the political, diplomatic, economic, and ideological conflict that developed after World War II between the United States and its allies and the Soviet Union and its allies (Fusfeld, 1998). However, as a way of 'seeing the world,' the Cold War is also an ideology validating various interventions, rather than active super-power conflict between the US and the Soviet Union (Carragee, 2003; Kelley, Mills \& Cooke, 2006). Media texts in the English language entwined Lenovo, as a Chinese company, with China, while representing the latter as potentially hostile to the US. Several texts aligned Lenovo at a national level with 'red' (communism and the Red Army) - its 'true colour' so to speak. The following is an example:

'Since CAS owns $65 \%$ of Legend, which in turn owns $46 \%$ of Lenovo, all CAS needs is $1.6 \%$ more of the voting share to take active managerial control over the board of Lenovo. That's not protectionism - that's a red flag!' (Manzullo in Wall Street Journal)

Here, the Chinese government's stake in Lenovo was referred to as 'a red flag' signalling both danger and political stance. Other texts also included representations of the acquisition as a threatening encounter embedded in 'Cold War' (Table 2). At times the Cold War was explicitly invoked. In reference to the full CFIUS review, associations were made in the texts to highlight the review's Cold War legacy as in this example from the New York Times:

'The IBM-Lenovo episode should prompt Congress to review the authority of the investment committee, which dates from the Cold War,' said Michael R. Wessel, a member of the United States-China Economic and Security Review Commission, a group established by Congress.

However, Cold War undertones were also present in other settings. For example, an article entitled 'Arming China, and Not' ran as follows:

Now, as Chinese companies eye US assets more acquisitively, fears are on the rise about the possible loss of economic power and the transfer of technology to a potentially hostile nation (Wall Street Journal).

Further to portraying the acquisition as 'arming China' in the title, the text represented China as 'potentially hostile.' In other acquisition accounts, Lenovo was implicated with China, which in contrast to the Western capitalism is a 'communist' country with 'ruling communists.' 
It runs a 'non-market economy which does not play by the rules of fair trade' (Manzullo quoted in Hitt, 2005). Also note this example in the Financial Times:

All the while, Beijing's ruling communists openly spurn notions of Western-style democratic reforms and continue to enforce their view that one-party rule is right for China.

In examining the intertextual relations across languages, Chinese texts also explicitly referred to the Cold War ideology in response to English-language representations of the acquisition. For example, in reflecting on the major reasons behind the scrutiny of Chinese companies’ international acquisitions, $21^{\text {st }}$ Century Business Report stated:

First is the Cold War way of thinking. The Chinese military expenditure adjustment is called a 'military threat' by the US, China's Peaceful Rising strategy is seen as a 'political threat,' and a few Chinese companies' participation in global business is considered an 'economic threat' ...

Other texts, however, included further suggestion that forms of 'imperialism' drive the tensions instigated 'business relations' are not discrete, but related to international relations:

Americans should be very familiar with the saying from the movie God Father: business is business. But the recent 'political economy' events are quite ironic. Lenovo's acquisition encountered difficulties because of 'political blockage'... Today, America's position has some characteristics resembling old 'Empires,' hence it can be called a 'New Empire' or 'Modern Empire'...To the US, its business relations with China are not only business, but are related to the national security strategy. America's national security strategy is to avoid any challenge to its imperialism from any big nations (Liberation Daily).

At times, texts explicitly link these dynamics to American nationalism as in Table 2. As the texts in the Table illustrate, whereas some Chinese-language articles frame such US nationalism as problematic for China, others laude the 'strong national pride' that companies such as Lenovo glean for China. In other words, the acquisition was not simply represented as a business activity; rather, it became an activity embedded in the politics of international relations.

\section{Globalism}

Whereas globalization is one of the central themes in international relations, focus here is on globalism as an ideology premised on the conviction that market deregulation and integration are inevitable, one that is often pitted against 'protectionism'. It is also normative, in that globalisation is advocated as a process that can benefit everyone (Steger, 2001). This ideology 
can conflict with the previous position on the acquisition as indicated through the intertextual resonance in the following texts in both languages, English (Wall Street Journal) and Chinese (21 $1^{\text {st }}$ Century Business Report):

Others see the controversy as protectionist backlash. The issue is mainly a 'concern of US isolationist forces who oppose globalization and economic integration,' Paul Denlinger, founder of China Business Strategy, a consulting firm that helps companies crack the Chinese market, wrote in a recent essay.

The difficulty [in the acquisition approval] indicates that Chinese companies who are aiming at going out can not neglect protectionism against foreign investment in developed countries.

From a globalist position, media texts in English presented the acquisition as a way of managing international relations with China as an emerging power by helping it to change:

The idea, Mr. Palmisano explained, would be to build a modern and truly international Chineseowned corporation. The move, he added, would demonstrate China's desire to take that next step toward economic maturity by investing abroad instead of merely serving as a manufacturing hub for the rest of the world (New York Times).

Such texts represented the acquisition as a step in enabling China to change towards Western economic expectations. Proponents of this position regarded the acquisition's approval after the CFIUS review as representative of the primacy of globalist ideology. This is addressed by quoting Ward, the new CEO, in an interview in the Wall Street Journal:

'I guess you need to decide if there should be world markets or if markets should be isolated. And to the extent you believe there should be world markets, already we've have this in the United States - with Japan, with Korea. I think what we're seeing with China is a very similar sort of thing.'

Globalisation can also involve a process of segregation (Friedman, 2003). Texts in English of the division of labour at an international level (through value system relations) indicate that China would take on the labour-intensive and lower-value manufacturing tasks, in contrast with the more innovative and lucrative service tasks that stay in the US. The argument is that since the PC business involves 'mature technologies' favouring 'economies of scale,' this justifies the sale of IBM PCD to China. The following is a typical example:

IBM was a PC pioneer, Gedwillo said, but he added that the systems have become commodities and that the sell-off may 'be an indicator of a company that is looking forward'... Daniel Menasce, a professor of computer science at George Mason University in Fairfax, Va., wasn't surprised by the sale. 'The profit margin on PCs is slim,' he said. 'IBM makes its money on selling solutions to 
its customers' (Computerworld).

This international division of labour was also discussed using the language of 'outsourcing' as in this BusinessWeek example:

Rather than sell its PC business outright, IBM ultimately decided to keep a 13.4\% stake in the combined company and as Liu (Lenovo Chairman prior acquisition) had hoped, contribute top IBM execs to help run it. In essence, IBM outsourced its PC business to Lenovo, and Lenovo outsourced much of its management and sales to IBM. As a result, the first major merger between an American company and a Chinese one is creating a true blend of East and West, of tech icon and industry upstart (Roberts and Lee 2005).

While the above text presents the acquisition as 'a true blend of East and West,' such blend was not of equal standing, but one of an 'icon' and an 'upstart,' each undertaking work representative of their respective standing. From the above position, it then followed that the globalisation of US corporate culture would enhance organizational practices worldwide. Texts highlighted Lenovo’s intention to adopt US business practices and philosophy as in the following example from an article in the New York Times titled 'Outsourcing to the US':

In recent years, Lenovo officials say the company's corporate culture has evolved from what some company officials called the 'semimilitary' culture that prevailed in the early days, to a more easygoing and hip high-tech culture ... And the new language for the company is English, company officials say ... Lenovo officials say they are studying American business history, and the chief executive lists The Harvard Business Review as part of his regular reading.

Rather than frame a perspective of Lenovo as enmeshed in a fixed 'true colour' (red), this position suggests that Lenovo can change - to be more like US organizations. Ironically, while it is IBM that was ailing, its business model was what was being adopted post-merger. Further, Anglicisation has gone with globalisation (Demont-Heinrich, 2005) and Lenovo’s decision to adopt English as the official language can be interpreted as one such consequence. Lenovo's Chinese employees would have to learn English in the future, as CEO Ward stated in his interview in the Wall Street Journal:

'[My Chinese] Not very good. Not good at all. Lenovo made a decision before the acquisition to run the company in English, which I think was a very good move on their behalf, and I will tell you that my colleagues are exceptionally strong in developing their English. Much better than I've been in my Chinese'...

Further, when organizational actors were cited, they presented the organizations as united 
by globalism in the face of external divisive discourses, emphasizing similarities that can enable them to overcome alleged obstacles. The following example comes from an interview in Newsweek with Yang Yuanqing, the chairman of new Lenovo, in which being 'global' is used to counteract perceptions of difference:

You'll be chairman of the new Lenovo, which has now acquired thousands of American employees. How will you bridge the culture gap and make them feel at home working for a Chinese company partly owned by your country's government? Yang: 'I aim to tell them Lenovo is not just a Chinese company but a global company. So the headquarters will be in New York and Stephen Ward - an IBM senior vice president - will be CEO. I'll also tell them there are many similarities between our two companies.'

Indeed, Lenovo statements quoted in the texts emphasize its 'global' positioning. Overall, representations presented the productive consummation of the acquisition as one of the impregnation of Lenovo with IBM language, practices and 'faces':

In the meantime, IBM has been aggressively meeting with its customers to explain the deal and assure them that IBMers will remain active in the company following the consummation of the deal, he said. Lenovo's new CEO, after all, will be Steve Ward, a long time IBM executive. Several other IBM faces will be there as well,' Robert Galush, vice president of product marketing in IBM's PC division, added (CNET News).

So from a position of globalism, such international acquisitions are actively lauded. The argument was that rather than approach difference as intrinsic and fixed, people should trust that Chinese firms can change, and also become more like their US counterparts. As such, it represents an evolutionary perspective on progress.

The intertextuality of globalism also flows through media accounts in Chinese that present the acquisition as accelerating Lenovo's attempts at 'international' and 'global' positioning:

Current Lenovo is not a grass-root company. It has an international brand and a mature global marketing and distribution system ... It can be expected that Lenovo will bring experience in building the global brand and marketing system ... but what is worth thinking about is whether Chinese capital will become the leader in technology and brand development (21 Century Business Report).

However, whereas the above text positions Lenovo as an already established international brand, this was in contrast to the following text in Liberation Daily in which the acquisition was represented as a 'short cut' towards becoming a global brand and business:

Journalist: What is the most important aspect in buying IBM PCD? 
Mr. Liu [Lenovo chairman]: The value is mainly in the brand, the global business system and PC technology. Building Lenovo into a global brand needs huge investment. Constructing a global business system needs time. Using IBM's existing business is a short cut.

And there was brief mention of firm internationalisation as a 'conquest':

... the future of Lenovo's acquisition will represent the future of many Chinese companies, who dream of conquering the world through manufacturing and marketing $\left(21^{\text {st }}\right.$ Century Business Report)

Relevant here is the intertextual variation in the motive. In contrast to English-language texts on the acquisition as the manufacturing share of an international division of labour (due to cheaper wages), Chinese-language texts presented the acquisition as symbolic of attempts in

China to move towards both the creative design and the corporate end of production:

Lenovo acquiring IBM PCD ... Chinese manufacturing companies have the courage to build brands in the international market ... Products should move from 'made in China' to 'designed/invented in China'... (21 ${ }^{\text {st }}$ Century Business Report)

Some people have already started to notice the 'white-collar job outsourcing' phenomenon: management jobs are shifting to developing countries. Lenovo's recent acquisition of IBM's PC division is a case in point (Lianhe Zaobao).

Altogether, both English- and Chinese-language texts iterated the tensions between the ideologies of both Cold War and globalism within each nation. So on the one hand, Lenovo's aspiration to become a 'global' firm through acquisition was a normative expectation of most successful organizations in the west; on the other hand, what renders this experience different was the relational history of the organizations' nations.

\section{Discussion and Conclusion: Intertextual Relations and International M\&As}

The purpose of this paper is to elucidate the relevance of the intertextual production of international relations in representations of M\&As. The premise is that texts map out relations across the world and come to frame context and meaning. Hence, it is paramount that we understand the intimate relationship between intertextuality, international relations and international management. We have focused on international M\&As as dramatic events that instigate reflections on nations in relation to other nations. Lenovo's acquisition of IBM PCD is 
a relevant case that merits attention in its own right; however, it also serves as a prime illustration for the intertextuality of international relations during M\&As and its relevance to organization and management studies. In what follows, we pull together the implications of this study by addressing our research questions which aim at identifying (i) the facets of international relations that surface in the media accounts and (ii) the intertextual dynamics entwined with the production of these international relations in this acquisition.

First, by focusing on constitutive intertextuality the analysis points to specific discursive themes that invoke the international relationship between the US and China. English-language texts include discussions of the acquisition as a 'threat' to US security and economy, while Chinese texts include notions of 'peaceful rising' or 'going out.' Such differences in framing relate to the specific relational history of these nations and the history of their experience with international ownership and restructuring. Central to the analysis is that Chinese texts respond to English coverage of the acquisition. Thus, intertextuality does not simply denote repetition but also responsive engagement in a way that attempts to change meanings for various constituents.

Second, analysis of manifest intertextuality demonstrates how international relations are textually produced through powerful emotion rhetoric. Attention to rhetorical performance enhances understanding of the everyday characteristics of international relations. Since intertextuality is core to the subtle production of the interrelationship between nations as 'imagined communities’ (Anderson, 1983), emotion rhetoric here served to illustrate the intertextual relationship between representations of national 'fear'/‘cheer.' This enabled both iteration and change, resonances of 'concern' on the one hand, and responses of 'success' on the other.

Third, intertextual inquiry also illustrates how the international relations written into organizational acquisitions are underlined by ideology. In this case, ideologies such as 'Cold War' and 'globalism' were reproduced in and through the media texts but with contradictory 
effects - the former working against the acquisition and the latter for it. Such ideologies come to impose specific ‘rules-of-the-game' for international acquisitions. Together, they construct an ideological ‘complex’ (Hodge \& Coronado, 2006) of competing geopolitical and geo-economic representations. So whereas M\&As are usually conceived as a 'business' activity commonly assigned to market and economic interests, this paper points to the centrality of both geopolitical (here Cold War) and geo-economic (here globalism) dynamics to such events. What shapes the remembering and the forgetting of the history of engagement (e.g., international relations and international management) and struggles (e.g. Cold War) is not simply psychological, but also textual - scripted and institutionalised in forms of representation (Shapiro, 1988, 2001).

The paper contributes to three discussions within organization and management studies. First, it adds a novel dimension to the literature on national identification in international management by casting the emphasis on international relations. Rather than focusing on cultural or national identities per se (Hofstede, 1980) - as entities - identification places emphasis on the processes by which such identity is created (Cornelissen et al, 2007). Previous research has illustrated and acknowledged the relevance of national identification (e.g. Ailon-Souday \& Kunda, 2003; Stelzl \& Seligman, 2009; Vaara et al., 2003); however, due to its limited examination, it has also called for further research into its processes (Vaara \& Tienari, 2011). This study brings into sharp relief the relevance of identity production more generally, but specifically the significance of examining the international relational dimensions whereby respective national interests and histories are juxtaposed, reinforced and contested in the process of identification. The portrayal of international relations, therefore, is entwined with the textual processes that shape national identity, both mutually defining one another.

Second, the paper contributes to a nuanced understanding of relationality in international M\&As. For example, ‘cultural differences' have been frequently used as explanations of challenges and problems in such events (Morosini, Shane \& Singh, 1998; Olie, 1994; Stahl \& 
Mendenhall, 2005). However, prior studies have often overlooked the international political and economic relations (and respective ideological premises) that serve to generate agreement or difference. In other words, the geographies of interest shaping 'culture' and 'state' borders may not always coincide. Hence, business relations premised on, and reinforcing of, the latter are worth critical examination in their own right.

Third, this paper also advances the intertextual approach to organizational analysis and theorization. While the contribution of intertextual analysis has been recognized in the organizational literature (e.g. Boje, 2001; Boje et al., 2004; Keenoy \& Oswick, 2003), its application has been limited. Further, through specific emphasis on media intertextuality (and its role in defining the nation in relation to other nations), our approach furthers the critical analysis of texts, thereby contributing to the literature on the role of the media in M\&As (e.g. Demers et al., 2003; Fitzgibbon \& Seeger, 2002; Fursich, 2002). By illustrating the variation in framing international interest through the political dynamics reproduced in texts, focus on intertextuality enables understanding of the ways in which specific discursive themes, rhetoric and underlying ideological assumptions are interrelated (Fairclough, 2003; van Dijk, 1998). Our analysis of the production of Sino-US relations in texts on organizational events could be followed by analyses of other national relational contexts. For example, it would be interesting to compare the findings here with representations of international relations in postcolonial settings or in contexts defined by close collaboration (such as US-Canada and Australia-New Zealand). Further, while we have highlighted emotion rhetoric, future analysis could provide insight into other linguistic resources deployed in producing international relations within organization.

The three facets to intertextual analysis in this paper also identified specific points that leave the reader with food for thought. First, 'national security' is a theme that has grown into an important dimension in contemporary international relations. While invoking the 'nation' serves as a mobilizing discourse (Freeden, 1998), its dynamics acquire new force when aligned with 
'security' discourse (Chilton, 1996). Security is a practice for interpreting foreign danger that leaves nothing to chance; it results in global surveillance and intervention, and it is also representative of structures of authority and control (Shapiro, 2001). In some ways, national security is becoming increasingly relevant to international M\&As, signalling that inquiry into cross-border acquisition is not simply a factor of economics, organization and management, but also of international politics. In this case, BusinessWeek had suggested, 'The IBM sale may go through, but experts expect the US to cast a more sceptical eye on future deals with China.' More recently, while lauding Lenovo as a 'stateless multinational', The Economist simultaneously questioned whether its acquisition of IBM PCD would have gone through in the current world climate. Indeed, several subsequent acquisition attempts by Chinese firms (e.g. of firms in the US and Australia) have been unsuccessful. Hence, the dynamics discussed in this paper bear relevance to other - not only Chinese - failed acquisition attempts also deemed a ‘security threat' (e.g., Dubai Ports World attempted acquisition of P\&O in 2006, and respective concerns over US ports security). The interesting question is how the mobilizing power of national security discourse is reconciled with the contradictory trends of globalisation and the arguments for globalism.

Second, whereas the textual production of international relations shapes accounts of M\&As, representations of acquisitions also offer a window into the textual dynamics of international relations. In particular, our analysis pointed to the role of emotion rhetoric in the media's portrayal of how people feel about events in the world, identifying 'fear' as one of the salient emotions produced. By 2007, ‘America’s fear of China' had made it to the cover of The Economist. Drawing from the final scene in King Kong, the image depicted a panda clinging to the top of the Empire State Building against a backdrop featuring the New York skyline dotted with circling blue and red helicopters attempting to control the situation (a visual rendering of Chow's 1998 metaphor). The editorial discussed the rising anxieties within the US towards 
economic and trade relations with China. Since then, the media catchphrase 'fear of China' (or 'sinophobia') has made repeat appearances in article titles discussing international acquisitions and other business activities. The reproduction of such emotion rhetoric blends the contours of international M\&As and international relations.

Third, while texts often reproduce the determinism of 'globalisation' and the normativity of 'globalism,' it is worth noting that even though the terms 'international' and 'global' are usually conflated, they hold distinctions. Attempts to quantify globalisation often conceive of it as internationalisation, a growth of transactions and interdependence between countries (e.g. gauged by foreign direct investment). Yet, there is 'a key distinction between 'international relations' (as exchanges between countries) and 'global relations' (as exchanges within the world)' (Scholte, 2005, p. 21). Whereas the conceptualisation of the 'globe' as a spatial unit enables a form of 'supra-territoriality,' the latter is not without its constraints. Multi-national corporations would have a long way to go before they realize an ideal of 'global relations'; in the meantime, as their name (multi-national) suggests, they operate within notions of territoriality and sovereignty, and their respective effects on organization.

In closing, we invite organizational scholars to consider the compelling rationales for examining the intertextual production of international relations. First, conceptions of international relations play a central role in national identification processes. Such relations and their representations are inherent to the dynamics of M\&As. Second, relational processes of national identification are influenced by international geopolitical and economic interests 'cross-border' not only 'cross-cultural' dynamics - that enable or constrain the context for a given merger or acquisition. Third, they alert us to the role of the relational history between nations in framing 'friend' and 'foe', a pattern that could shape evaluations of acquisitions by organizations from 'other' nations. Simultaneously, they remind us of the ongoing ambivalence towards processes of globalization that unite organizations across borders through economic 
interdependence while also invoking sentiments of national economic threat through potential loss of jobs and erosion of security. Last but not least, the discourses, rhetoric and ideologies of international relations pervade daily news texts with which people engage to make sense of their place in a world made of nations. These intertextual streams do not stop outside accounts of international management and organization; rather, they seep through them to reach their respective national audiences. Here we come back full circle to the argument forwarded in this paper that international M\&As are immersed in a seascape of intertextual international relations. 


\section{References}

Aguilera, R. V., \& Dencker, J. D. (2004). The role of human resource management in crossborder mergers and acquisitions. International Journal of Human Resource Management, 15(8), 1355-1370.

Ailon, G., \& Kunda, G. (2009). The one company approach: Transnationalism in an IsraeliPalestinian subsidiary of a multinational corporation. Organization Studies, 30(7), 693-712.

Ailon-Souday, G., \& Kunda, G. (2003). The local selves of global workers: The social construction of national identity in the face of organizational globalisation'. Organization Studies, 24(7), 1073-1096.

Akhan-Majid, R \& Ramaprasad, J. (1998) Framing and ideology: A comparative analysis of the US and Chinese newspaper coverage of the fourth United Nations Conference on Women and the NGO forum. Mass Communication and Society, 1(3/4): 131-152.

Anderson, B. (1983). Imagined communities: Reflections on the origin and spread of nationalism. London: Verso Editions and NLB.

Bakhtin, M. (1981). The dialogic imagination. Austin: The University of Texas.

Bakhtin, M. (1986). Speech genres and other late essays. Austin: The University of Texas.

Beer, F., \& De Landtsheer, C. (2004). Metaphors, politics, and world politics. In F. Beer \& C. Landtsheer (Eds.), Metaphorical world politics (pp. 5-54). East Lansing, MI: Michigan University Press.

Billig, M. (1995). Banal nationalism. London: Sage.

Boje, D. (2001). Narrative methods for organizational communication research. London: Sage.

Boje, D., Rosile, G. A., Durant R., \& Luhman, J. (2004). Enron spectacles: A critical dramaturgical analysis. Organization Studies, 25(5), 751-774.

Calori, R., Lubatkin, M., \& Very, P. (1994). Control mechanisms in cross-border acquisitions: an international comparison. Organization Studies, 15(3), 361-380.

Carragee, K. M. (2003). Evaluating polysemy: An analysis of the New York Times' coverage of the end of the Cold War. Political Communication, 20, 287-308.

Chang, T K, Wang, J. \& Chen, C H (2006) News as social knowledge in China: The changing worldview of Chinese national media. Journal of Communication, 44(3): 52-69.

Chilton, P. (1996). The meaning of security. In F. A. Beer \& R. Hariman (Eds.), Post-Realism: The Rhetorical Turn in International Relations (pp. 193-216). East Lansing: Michigan State University Press.

Chow, R. (1998) King Kong in Hong Kong: Watching the 'handover' from the USA. Social 
Text, 16(2): 93-108.

Comtois, E., Denis, J-L., \& Langley, A. (2004). Rhetorics of efficiency, fashion and politics: Hospital mergers in Quebec. Management Learning, 35, 303-320.

Cornelissen, J. P., Haslam, S. A., \& Balmer, J. M. (2007) Social identity, organization identity and corporate identity: Towards an integrated understanding of processes, patternings and products. British Journal of Management, 18, S1-16.

Coupland, C., Brown, A. D., Daniels, K., \& Humphreys, M. (2008). Saying it with feeling: Analysing speakable emotions. Human Relations, 61(3), 327-353.

Cummings, S., \& Riad, S. (2007). M\&A as warfare: Warspeak in mergers and acquisitions. In D. Angwin (Ed.), Mergers and Acquisitions. (pp.87-115). London: Blackwell.

Demers, C., Giroux, N., \& Chreim, S. (2003). Merger and acquisition announcements as corporate wedding narratives. Journal of Organizational Change Management, 16, 223-242.

Der Derian, J. (1989). The boundaries of knowledge and power in international relations. In. J. Der Derian \& M. J. Shapiro (Eds.), International/Intertextual Relations (pp.3-10). New York: Lexington Books.

Demont-Heinrich, C. (2005). Language and national identity in the era of globalization: The case of English in Switzerland. Journal of Communication Inquiry, 29(1), 66-84.

Doveling, K., von Cheve, C., \& Konjin, E. (2011, eds.) The Routledge handbook of emotions and mass media. New York, NY: Routledge.

Doyle, R. (2007) America and China: Asia-Pacific rim hegemony in the twenty-first century. Plymouth, UK: Lexington Books.

Edwards, D. (1999) Emotion discourse. Culture \& Psychology, 5(3): 271-291.

Encyclopaedia Britannica (2011) International relations. www.britannica.com

Fairclough, N. (1989). Language and power. London: Longman.

Fairclough, N. (1992). Discourse and social change. Cambridge, UK: Polity Press.

Fairclough, N. (1995). Media discourse. London: Edward Arnold.

Fairclough, N. (2003). Analysing discourse: Textual analysis for social research. London: Longman.

Fairclough, N., \& Thomas, P. (2004). The discourse of globalization and the globalization of discourse. In D. Grant, C. Hardy, C. Oswick, \& L. L. Putnam (Eds.), The Sage Handbook of Organizational Discourse (pp. 379-396). London: Sage.

Fitzgibbon, J. E., \& Seeger, M. W. (2002). Audiences and metaphors of globalization in the 
Daimler Chrysler AG merger. Comunication Studies, 53(1), 40-55.

FMPRC (Ministry of Foreign Affairs of the People's Republic of China) 2011. 30 years of SinoUS Relations. www.fmprc.gov.cn

Frauenheim, E. (2005). China closing the tech gap? CNET News. April 1.

Freeden, M. (1998). Is nationalism a distinct ideology? Political Studies, 46(4), 748-766.

Friedman, J. (2003). Globalizing languages: Ideologies and realities of the contemporary global system. American Anthropologist, 105(4), 744-752.

Fursich, E. (2002). Nation, capitalism, myth: Covering news of economic globalisation. Journal of Journalism and Mass Communication Quarterly, 79(2), 353-373.

Fusfeld, D. R. (1998). Economics and the cold war: An inquiry into the relationship between ideology and theory. Journal of Economic Issues, 32(2), 505-7.

Gellner, E. (1983). Nations and nationalism. Oxford, UK: Blackwell,.

George, J. (1994). Discourses of global politics: A critical (re)introduction to international relations. Boulder: Lynne Rienner.

Goulet, P. K., \& Schweiger, D. (2006). Managing culture and human resources in mergers and acquisitions. In G. Stahl \& I. Björkman (Eds.), Handbook of research in international human resource management (pp. 405-429). Cheltenham, UK: Edward Elgar.

Guan, Y. L. (2004). Lenovo jumps into the deep water to get treasure. Lianhe Zaobao. December 15.

Guthrie, D. (2003). The quiet revolution: The emergence of capitalism. Harvard International Review, 25(2), 48-53.

Hirsch, P. M. (1986). From ambushes to golden parachutes: Corporate takeovers as an instance of cultural framing and institutional integration. American Journal of Sociology, 91, 800-837.

Hitt, G. (2005). U.S.-China tensions play out in deal probe; High-level review of Lenovo's plan to buy IBM unit seems to have political overtones. Wall Street Journal, February 10: A 4.

Hodge, B., \& Coronado, G. (2006). Mexico Inc.? Discourse analysis and the triumph of managerialism. Organization, 13(4), 529-547.

Hofstede, G. (1980). Culturés consequences: International differences in work-related values. London: Sage Publications.

Holden, P. (2006). Putting the nation back into the transnational: Chinese self-fashioning and discipline in Singapore. In M. Ng, \& P. Holden (Eds.), Reading Chinese Transnationalisms: (pp. 63-74). Hong Kong: Hong Kong University Press. 
Kang, L. (2004). Globalisation and Cultural Trends in China. Honolulu: University of Hawai'i Press.

Kelley, E. S., Mills, A. J., \& Cooke, B. (2006). Management as a Cold War phenomenon. Human Relations, 59(5), 603-610.

Kelly-Holmes, H. (2000). Strong words softly spoken: Advertising and the intertextual construction of Irishness. In U. H. Meihof, \& J. Smith (Eds.), Intertextuality and the Media: (pp. 18-42). Manchester University.

Koller, V. (2005). Critical discourse analysis and social cognition: Evidence from business media discourse. Discourse and Society, 16(2), 199-224.

Keenoy, T., \& Oswick, C. (2003). Organizing textscapes. Organization Studies, 25(1), 135-142.

Kristeva, J. (1980). Desire in language. New York: Columbia University Press.

Lapid, Y. (1996). Nationalism and realist discourse of international relations. In F. Beer, \& R. Hariman (Eds.), Post-realism: The rhetorical turn in international relations (pp. 239-256). Michigan: Michigan State University Press.

Li, H. (2005). The Chinese path of economic reform and its implications. Asian Affairs: An American Review, 31(4), 195-211.

Lubatkin, M., Calori, R., Very, P., \& Veiga, J. F. (1998). Managing mergers across borders: A two-nation exploration of a nationally bound administrative heritage. Organization Science, 9, 670-685.

McDougall, D. (2006). Asia Pacific in world politics. Boulder, Colorado: Lynne Rienner.

Meinhof, U., \& Smith, J. (2000). The media and their audience: intertextuality as paradigm. In

U. H. Meihof, \& J. Smith (Eds.), Intertextuality and the Media (pp. 1-17). Manchester:

Manchester University Press.

Merriam-Webster Dictionary (2011). International relations. www.merriam-webster.com

Milliken, J. (1999). The study of discourse in international relations: A critique of research and methods. European Journal of International Relations, 5(2), 225-254.

Morgan, G., Kristensen, P. H., \& Whitley, R. (Eds) (2001). The multinational firm: Organizing across institutional and national divides. Oxford, UK: Oxford University Press.

Morosini, P., Shane, S., \& Singh, H. (1998). National cultural distance and cross-border acquisition performance. Journal of International Business Studies, 29, 137-157.

Niemeyer, K. \& Pricopie, V. (2007) New and old frontiers of Europe: Rhetoric of emotion in the media. Studia Universitatis Babes-Bolyai, Studia Europaea, 52(2): 193-212. 
Olie, R. (1994). Shades of culture and institutions in international mergers. Organization Studies, 15, 381-405.

Özkirimli, U. (2000). Theories of Nationalism. London: Macmillan

Pain, R., \& Smith, S. (2008). Fear: Critical geopolitics and everyday life. In R. Pain, \& S. Smith (Eds.), Fear: Critical geopolitics and everyday life (pp. 1-24). Hampshire, UK: Ashgate.

Puranam, P., Singh, H., \& Zollo, M. (2006). Managing the coordination-autonomy dilemma in technology acquisitions. Academy of Management Journal, 49, 263-280.

Quack, S., Morgan, G., \& Whitley, R. (Eds). (2000). National capitalisms, global competition and economic performance. Amsterdam: John Benjamins Publishing.

Riad, S. (2005) The power of 'organizational culture' as a discursive formation in merger integration. Organization Studies, 26(10), 1529-1554.

Riad, S. \& Vaara, E. (2011) Varieties of national metonymy in media accounts of international mergers and acquisitions. Journal of Management Studies, 48(4): 737-771.

Rochester, J.M. (2010). Fundamental principles of international relations. Westview Press.

Schlosser, K. (2007). The bio-politics of bodies politic: Nature and intertextuality in classic U.S. geopolitical discourse. Geojournal, 69(3), 199-211.

Scholte, J. A. (2005) Globalisation and the rise of super territoriality. In G. LaChapelle, \& S. Paquin (Eds.), Mastering globalisation: new sub-states' governance and strategies (pp. 13-37). London: Routledge.

Schuman, M. (2006). Lenovo’s global gambit. Time, September 25: 55.

Schneider S. C., \& Dunbar, R. L. M. (1992). A psychoanalytic reading of hostile takeover events. Academy of Management Review. 17, 537-567.

Shapiro, M. J. (2001). Textualizing global politics. In M. Wetherell, S. Taylor, \& S. J. Yates (Eds.), Discourse theory and practice (pp. 318-323). London: Sage.

Shapiro, M. J. (1989). Textualizing global politics. In J. Der Derian, M. J. Shapiro (Eds.), International/Intertextual Relations (pp. 11-22). New York: Lexington Books.

Smith, A. D. (2001). Nationalism: Theory, ideology, history. London: Polity Press.

Søderberg, A.-M., \& Holden, N. (2002). Rethinking Cross Cultural Management in a Globalizing Business World. International Journal of Cross Cultural Management, 2, 103-121.

Song, Y. (2006). Encyclopaedia of Chinese-American relations. McFarland. 
Steger, M. B. (2001). Globalism: The New Market Ideology. New York: Rowman \& Littlefield.

Stelzl, M. \& Seligman, C. (2009) Multiplicity across cultures: Multiple national identities and multiple value systems. Organization Studies, 30 (9): 959.

Stuckey, M. E. (1995). Competing foreign policy visions: Rhetorical hybrids after the Cold War. Western Journal of Communication, 59(3), 214-227.

Sutherland, C. (2005). Nation-building through discourse theory. Nations and Nationalism, 11(2), 185-202.

Tan, J., \& Tan, D. (2003). A dynamic view of organizational transformation: The changing face of Chinese SOEs under transition. Journal of Leadership and Organizational Studies, 10(2), 98112.

The Economist (2006). PC politics: Classify this. 27 May: 56.

The Economist (2007). America’s fear of China; Trade and economy. 19 May: 13.

The Economist (2009). The odd couple. 24 October: 15.

The Economist (2010). Friends, or else. 4 December: 13.

Tienari, J., Vaara, E. \& Björkman, I. (2003). Global capitalism meets national spirit: Discourses in media texts on a cross-border acquisition. Journal of Management Inquiry, 12(4), 377-393.

Titcher, S., Meyer, M., Wodak, R., \& Vetter, E. (2000). Methods of Text and Discourse Analysis. London: Sage.

Tsoukas, H. (1989) The validity of idiographic research explanations. Academy of Management Review 14: 551-561.

Vaara, E. (2002). On the discursive construction of success/failure in narratives of post-merger integration. Organization Studies, 23(2), 213-250.

Vaara, E., \& Tienari, J. (2011). On the narrative construction of multinational corporations: An antenarrative analysis of legitimation and resistance in a cross-border merger. Organization Science, 22(2): 370-390.

Vaara, E., Tienari, J., \& Laurila, J. (2006). Pulp and paper fiction: On the discursive legitimation of global industrial restructuring. Organization Studies, 27, 789-810.

Vaara, E., Tienari, J., \& Säntti, R. (2003). The international match: Metaphors as vehicles of social identity-building in cross-border mergers. Human Relations, 56, 419-452.

Van Dijk, T. A. (1998). Ideology: A Multidisciplinary Analysis. Sage, London. 
Vargova, M. (2007). Dialogue, pluralism, and change: The intertextual constitution of Bakhtin, Kristeva, and Derrida. Res Publica, 13, 415-440.

Wu, X. (2005). Who is bothered by Chinese brands? China Computer World. July 18.

Yuan, J.D. (2002). US vs China: A new Cold War? Asia Times Online. 28 September.

Zhang, X. (1998) Nationalism, mass culture and intellectual strategies in post-Tiananmen China. Social Text, 16(2).

Zhijun, L. (2006). The Lenovo affair: The growth of China's computer giant and its takeover of $I B M-P C$. Singapore: Wiley.

Zu, Z. (2007). Reform without a theory: Why does it work in China? Organization Studies, 28(10), 1503-1522. 
Figure 1 - The intertextual analysis of international relations in international M\&As

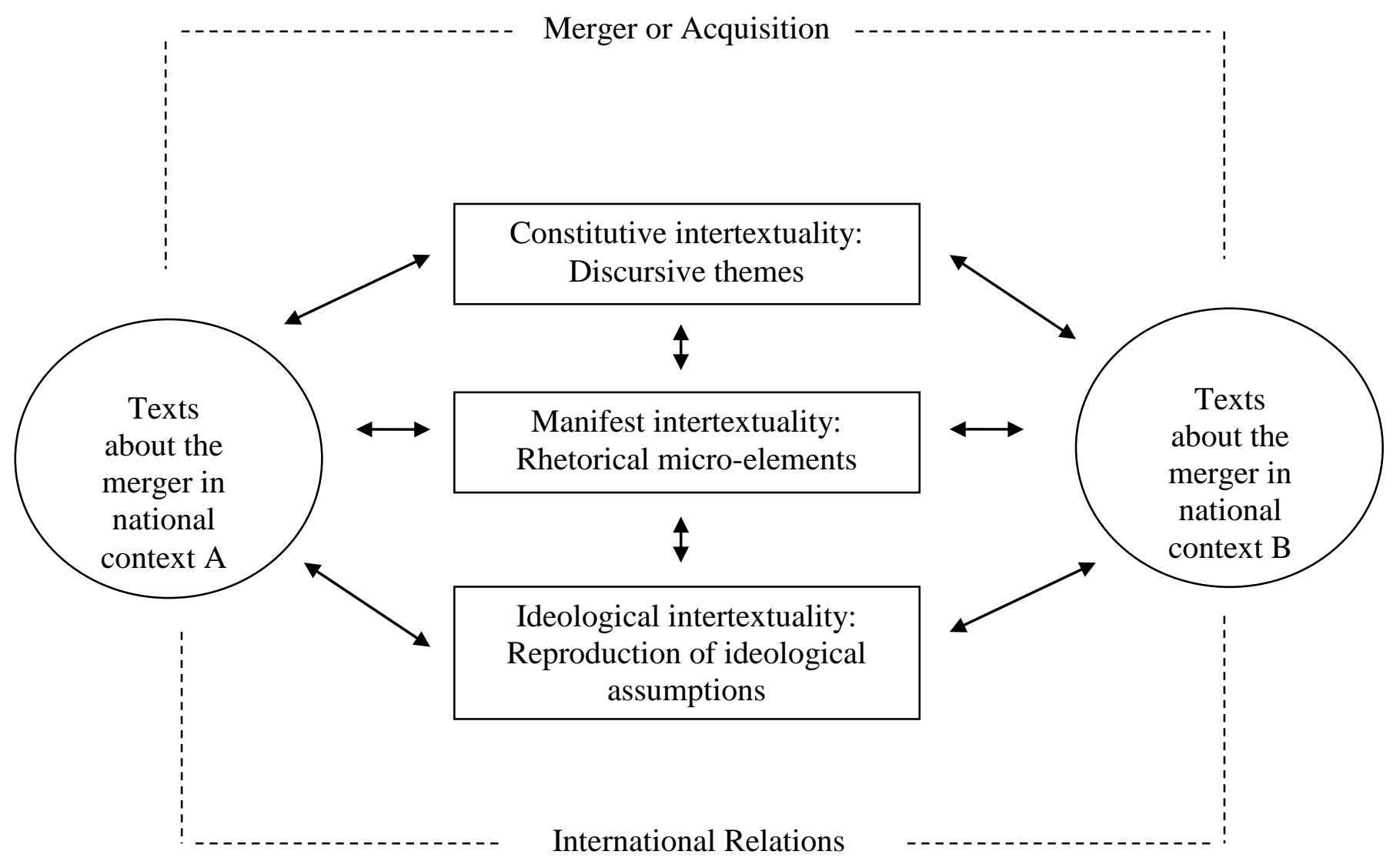


Table 1: Timeline of key events in the Lenovo/IBM acquisition (compiled through secondary sources)

\begin{tabular}{ll}
\hline Time & Event \\
\hline May 2002 & $\begin{array}{l}\text { Palmisano, IBM CEO, directed John Joyce, then IBM's CFO, to meet } \\
\text { with Lenovo's senior management to communicate the company's } \\
\text { interest in establishing a business relationship }\end{array}$ \\
\hline July 2003 & Palmisano travelled to Beijing to explore the sale of the company's PCD \\
\hline November 2003 & $\begin{array}{l}\text { Lenovo CFO Mary Ma travelled to New York to investigate the } \\
\text { possibility of Lenovo buying IBM PCD }\end{array}$ \\
\hline February 2004 & Palmisano visited Lenovo Chairman Liu Chuanzhi in Beijing \\
\hline 7 December 2004 & The announcement of Lenovo's intent to acquire IBM PCD \\
\hline End December 2004 & IBM and Lenovo applied for CFIUS review on the deal \\
\hline 27 January 2005 & Lenovo shareholders approved the acquisition \\
\hline 11 January 2005 & $\begin{array}{l}\text { The Federal Trade Commission in the US granted permission for the } \\
\text { acquisition }\end{array}$ \\
\hline 9 March 2005 & The extended CFIUS review cleared \\
\hline 31 March 2005 & $\begin{array}{l}\text { Three investors confirmed their plan to invest \$350 million in new } \\
\text { Lenovo (detracting from Chinese Academy of Sciences stake) }\end{array}$ \\
\hline May 2005 & $\begin{array}{l}\text { Lenovo announced that the acquisition transaction process has been } \\
\text { completed }\end{array}$ \\
\hline
\end{tabular}




\section{Table 2}

\section{Intertextual production of international relations in the Lenovo - IBM PCD acquisition}

Facet of analysis
English-language media texts

\section{Chinese-language media texts}

\section{Constitutive intertextuality: Threat to US security and economy}

Discursive themes
There's good reason, though, to pay attention to the deal and what it means about China. First, China is more advanced in the use of technology than many people know... The second big reason to pay attention to

China's technological rise is that it's happening faster here than it did elsewhere in Asia...

The 'national security' concerns surrounding the IBM deal are voiced by Michael Wessel, a member of a Congressional panel that monitors Sino-US transactions, the US-China Economic and Security Review Commission. He told the Washington Post that Chinese computer experts could conduct industrial espionage from IBM facilities. Another concern is that technologies that Lenovo acquired in the deal could have a 'dual use' and enhance the capability of the People's Liberation Army.

\section{China's 'peaceful rising' when 'going out'}

Chinese companies have to realize the risk associated with international acquisition. The risk of politicization makes normal business activities complex ...

From a suspicious concept, China Rising has become a common view ... Lenovo's recent acquisition of IBM's PC Division is a case in point.

The Foremost Problem of the Peaceful Rising [Article title] ... When Lenovo announced the acquisition, the US's nervousness was due to fear of China's economic rising.

We can anticipate that Chinese companies' international acquisition will accelerate continuously. The reason for this forecast is that the Chinese government will implement and support the 'going out' policy in long term.

\section{Manifest intertextuality:} Emotion rhetoric

\section{Fear and concern}

The proposed \$1.25 billion IBM-Lenovo deal heightened concern in Washington over China's increasing economic power and technological sophistication.

\section{Cheer and pride}

Lenovo acquiring IBM PCD has generated a global discussion on 'snake eats elephant'. 
But Mr. Raymond, like many other ThinkPad cultists, is worried that his laptop of choice will lose its edge when IBM completes the $\$ 1.25$ billion sale of its PC division to China's Lenovo Group Ltd., heretofore a maker of cut-price merchandise.
Journalist: Is it true that the PC industry is going downhill? Mr. Liu: On the contrary, the PC is going through a new technology revolution .......we are celebrating the increasing international importance of Chinese companies; we cheer for Chinese companies with strong national pride ...

\section{Ideological intertextuality}

\section{Cold War vs. Globalism}

After a federal panel cleared the sale of International Business Machines' personal-computer unit to a Chinese firm following a national-security review, Illinois Rep Manzullo suggests updating a law on such investments to embrace protection of 'economic security' as well. 'It's a Cold War remedy that has to be brought up-todate,' says the Small Business Committee chair.

The only way those changes will come is for the West to continue to engage China commercially, culturally and politically.

\section{Cold War vs. Globalism}

The reason for investigating Chinese firms particularly hard is that China represents the 'hostile' ideology and political system in US media rhetoric. Further, China's economic development has increased the perceived possibility of challenging US imperialism. This has provoked the internal ambivalence of US nationalism ...

To realize high speed growth, Lenovo sets the vision as: high tech Lenovo, service Lenovo, international Lenovo ... Facing the frustration [in internationalization], Lenovo adjusts its market position and multi business elements. IBM selling its PCD accelerates Lenovo's step towards internationalization and focus on PC... 


\section{Author bios}

Sally Riad is a Senior Lecturer at Victoria University of Wellington. Her research interests have increasingly focused on analysing the social facets of organization and difference. Her published work is based on critical approaches to a range of organizational topics including culture, mergers and acquisitions and leadership.

Nathan Zhang completed a Master's in Commerce and Administration (Management) at Victoria University of Wellington where he also worked as a research assistant. He is currently pursuing his passion for a life at sea, working in an inter-national capacity.

Eero Vaara is Professor of Management and Organization at Hanken School of Economics in Helsinki, Finland, and permanent Visiting Professor at EM Lyon Business School, France. His research interests focus on strategy and strategizing, organizational change, multinational corporations and globalization, management education, and methodological issues in management research. He has worked especially on discursive and narrative perspectives. 